Journal of
Nutrigenetics
Nutrigenomics
J Nutrigenet Nutrigenomics 2013;6:16-31

DOI: $10.1159 / 000345826$

Received: May 29, 2012

Accepted: November 3, 2012

Published online: February 22, 2013

\title{
The Emerging Role of MicroRNAs in the Regulation of Gene Expression by Nutrients
}

\author{
Laura García-Segura Martha Pérez-Andrade Juan Miranda-Ríos \\ Unidad de Genética de la Nutrición, Departamento de Biología Molecular y Biotecnología, \\ Instituto de Investigaciones Biomédicas de la Universidad Nacional Autónoma de México e \\ Instituto Nacional de Pediatría, México, México
}

\section{Key Words}

MicroRNAs · Gene expression • Diet

\begin{abstract}
MicroRNAs (miRNAs) are a class of evolutionarily conserved, small non-coding RNAs of 19-24 nucleotides in length that regulate gene expression mostly at the posttranscriptional level. They are known to be involved in the control of different processes such as cell cycling, programmed cell death, cell differentiation, tumor development, metastasis, and sensing of nutrient stress. This review summarizes the evidence regarding the changes in miRNA expression that are caused by diets with a deficiency or augmented intake of nutrients such as amino acids, carbohydrates, fatty acids, vitamins, and phytochemicals. As diet is known to influence the expression of miRNAs, miRNA profiling has the potential to be useful in the assessment of nutritional status in dietary intervention studies. Additionally, as it can change miRNA expression, diet may be used as a therapeutic agent to treat many different diseases. Also, we explored here some ideas on therapeutics based on the manipulation of miRNA expression levels for dietaryderived diseases as well as the putative effect of food-derived miRNAs on host gene expression.
\end{abstract}

Copyright $\odot 2013$ S. Karger AG, Basel

\section{Introduction}

Animals need essential dietary factors for normal growth, maintenance, repair, and reproduction. Such factors are acquired through diet and by the microbiological activity present in the intestines. As a matter of fact, an interesting relationship has been observed be- 
tween diet and the bacterial populations (enterotypes) inhabiting the gut as enterotypes are determined by the type of food ingested, regardless of sex or body mass index [1]. The use of currently available high-throughput 'omics' technologies has been crucial for obtaining a more detailed picture about nutrient acquisition, assimilation, and metabolism at the molecular level. One result of such studies has been the recognition of nutrients having another important role, that of determining gene expression, being the foundation of the science of nutrigenomics [2].

Recently, non-coding RNA molecules endowed with regulatory functions have been discovered in prokaryotic and eukaryotic organisms. In bacteria, they are dubbed as small RNAs due to their size that ranges from 35 to 300 nucleotides and have been shown to modulate mRNA translation and/or stability by base pairing to their targets or, in other cases, to modify protein activity [3]. In eukaryotes, two main classes of regulatory RNAs have been recognized: microRNAs (miRNAs) and small interfering RNAs (siRNAs). Although both are small (19-24 nucleotides), they differ in their biogenesis. While siRNAs are generated from double-stranded RNA precursor molecules derived from mRNAs, heterochromatic DNA, viral DNA, or transposons, miRNAs are processed from stem-loop regions of longprecursor transcripts (for a recent review, see [4]).

miRNAs are usually transcribed by RNA polymerase II, giving rise to long miRNA precursors that are capped and polyadenylated, termed primary miRNA (pri-miRNA), that fold into a hairpin loop structure (fig. 1). This double-stranded RNA structure is recognized by DiGeorge syndrome critical region 8 (DGCR8) and associates with the enzyme Drosha to form the 'microprocessor' complex. The interaction between the pri-miRNA and the microprocessor complex liberates the hairpin regions by cleaving the pri-miRNA, resulting in the formation of the pre-miRNA (precursor miRNA) (fig. 1). Pre-miRNAs are then exported from the nucleus by way of exportin-5. In the cytoplasm, the pre-miRNA hairpin is cleaved by the enzyme Dicer, yielding a miRNA:miRNA* duplex about 22 nucleotides in length. In principle, either strand of the duplex can become a mature miRNA, but usually only one strand is incorporated into the RNA-induced silencing complex (RISC), composed of Argonaute (Ago) proteins, that bind the mature miRNA and orient it to facilitate the interaction with its target mRNA (fig. 1). miRNAs usually regulate gene expression at the posttranscriptional level by binding to the 3' UTR of mRNAs [5] (fig. 1). In plants, such binding leads to the cleavage of the target mRNA, while in animals it controls translation initiation [4] (fig. 1). Additionally, miRNAs can act at the transcriptional level as it has been reported that binding of miRNAs to promoter regions is able to trigger what is known as transcriptional gene silencing of nuclear genes, showing that cytoplasmically processed miRNAs can be transported to the nucleus [6]. It has been calculated that nearly $60 \%$ of all mammalian mRNAs represent miRNA targets [7].

Initially, miRNAs were thought to be mainly involved in the regulation of development and cell fate, but the identification of additional miRNAs and their target genes led to the discovery that miRNAs participate in a broad range of processes such as cell cycling, programmed cell death, cell differentiation, tumor development, invasion, metastasis, and angiogenesis. Recently, a few miRNAs have been identified that are involved in sensing nutrient stress in plants [8]. Undoubtedly, miRNAs are key important factors in the response to environmental stress as they help to restore homeostasis in cases of sudden environmental changes or, if the stress condition is severe and of long duration, represent one mechanism used to reprogram gene expression so the cells can adapt to a changing environment $[9,10]$.

This review summarizes the evidence regarding the influence of phytochemicals and nutrients such as amino acids, carbohydrates, fatty acids, and vitamins on miRNA gene expression in animals as well as their physiological consequences. We also explored the potential uses of miRNAs as new therapeutic agents for dietary-derived disorders and the putative effect of food-derived miRNAs to influence host gene expression. 
García-Segura et al.: The Emerging Role of MicroRNAs in the Regulation of Gene Expression by Nutrients

Fig. 1. miRNA biogenesis and related gene silencing mechanisms.

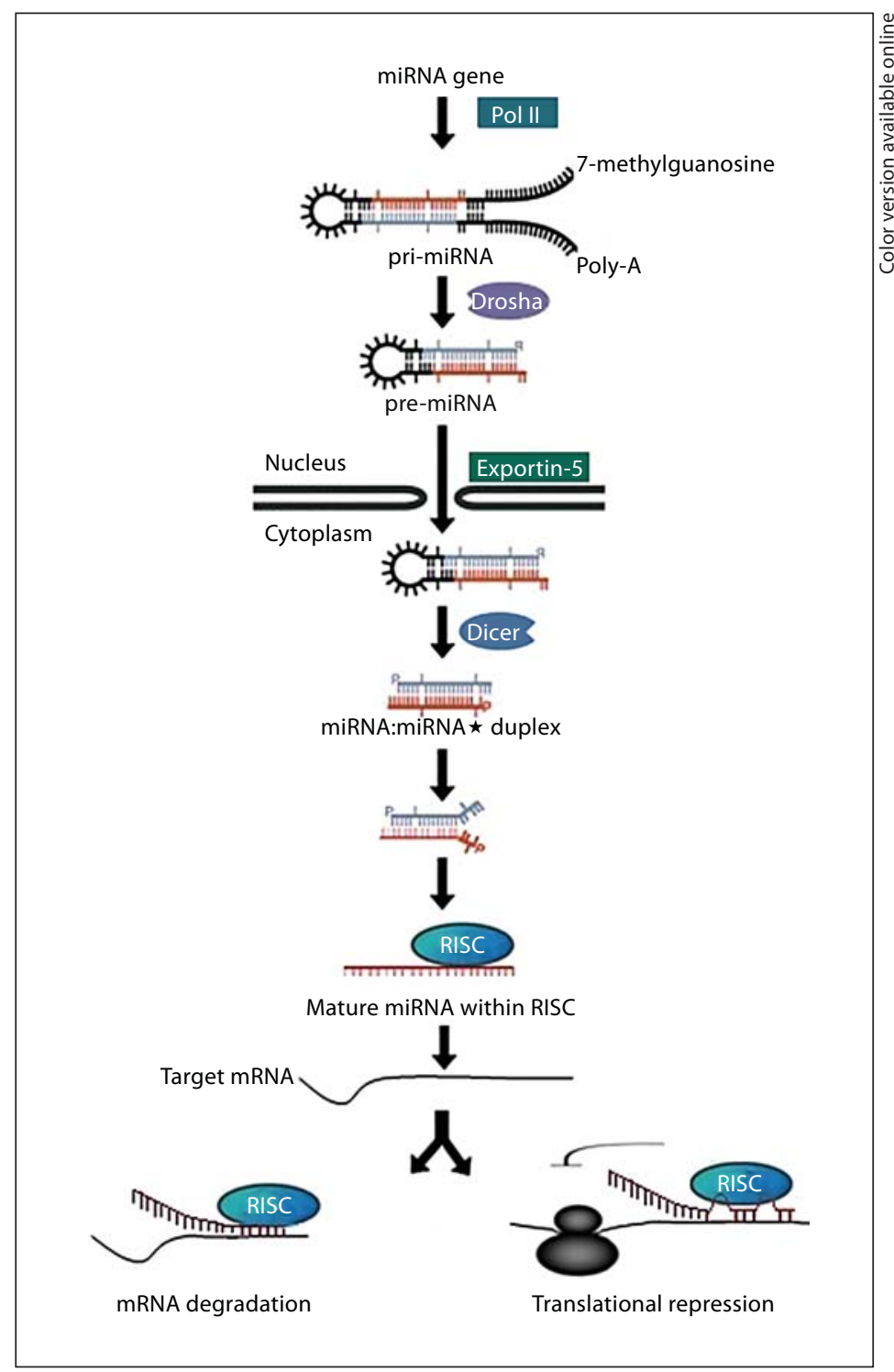

\section{Effect of Macro- and Micronutrients on miRNA Expression}

Diverse dietary components such as amino acids, carbohydrates, fatty acids, and vitamins have been found to affect the expression profile of miRNAs or their function (table 1).

\section{Macronutrients Found to Have an Impact on miRNA Expression}

Amino Acids

An amino acid-deficient diet can lead to changes in miRNA expression. When a methionine-choline-deficient diet was fed to mice, the animals showed liver steatosis, liver injury, and nonalcoholic fatty liver, signs of diet-induced nonalcoholic fatty liver disease. Under such conditions, the expression of miR-182, -183, -199a, -705, and -1224 was upregulated [11]. Although a similar disease known as alcohol fatty liver is caused by feeding mice a LieberDeCarli alcohol diet, some differences in the expression of miR-182, -183, and -199a were observed as these miRNAs were by contrast downregulated, while the expression of miR-705 
Table 1. Macronutrients known to affect the expression of miRNAs

\begin{tabular}{|c|c|c|c|}
\hline miRNA & Change & Type of cells & Reference \\
\hline \multicolumn{4}{|l|}{ Amino acids } \\
\hline \multicolumn{4}{|l|}{ Methionine deficiency } \\
\hline miR-182, $-183,-199 a,-705,-1224$ & $\mathrm{U}$ & murine liver & 11 \\
\hline \multicolumn{4}{|l|}{ Amino acid deprivation } \\
\hline miR-122 & I & human hepatoma cells & 12 \\
\hline \multicolumn{4}{|l|}{ Essential amino acids } \\
\hline miR-1, -23a, -208b, -499, pri-miR-206 & $\mathrm{U}$ & human skeletal muscle biopsy & 13 \\
\hline \multicolumn{4}{|l|}{ Carbohydrates } \\
\hline \multicolumn{4}{|l|}{ Glucose } \\
\hline $\operatorname{miR}-29 c$ & $\mathrm{U}$ & mouse podocyte cell lines & 14 \\
\hline miR-21 & $\mathrm{U}$ & mouse renal mesangial cells & 15 \\
\hline \multicolumn{4}{|l|}{ Fatty acids } \\
\hline \multicolumn{4}{|l|}{ Butyrate } \\
\hline miR-10a, $-24,-122,-192,-375$ & $\mathrm{U}$ & human embryonic stem cells & 17 \\
\hline \multicolumn{4}{|l|}{$\mathrm{n}-3$ polyunsaturated fatty acids } \\
\hline let-7d, miR-15b, -107, -191, -324-5p & $\mathrm{U}$ & rat colon & 18 \\
\hline \multicolumn{4}{|l|}{ High-fat diet } \\
\hline let-7a, let-7b, let-7c, miR-26a, -122, & & & \\
\hline$-192,-194,-483^{*},-494,-709$ & $\mathrm{D}$ & murine liver & 19 \\
\hline $\operatorname{miR}-27,-122,-451$ & $\mathrm{D}$ & rat liver & 21 \\
\hline miR-200a, $-200 b,-429$ & $\mathrm{U}$ & & \\
\hline miR-16, -103, -107, -451 & $\mathrm{D}$ & murine liver & 22 \\
\hline $\operatorname{miR}-351,-669 c$ & $\mathrm{U}$ & & \\
\hline miR-143-145 cluster & $\mathrm{U}$ & murine liver & 23 \\
\hline miR-103, -107 & $\mathrm{U}$ & murine liver & 24 \\
\hline \multicolumn{4}{|l|}{ Conjugated linoleic acid } \\
\hline miR-107, -143 & $\mathrm{D}$ & murine retroperitoneal & 25 \\
\hline miR-222 & $\mathrm{U}$ & adipose tissue & \\
\hline
\end{tabular}

and -1224 was upregulated as in the case of mice fed a methionine-choline-deficient diet [11]. Even though more studies are needed to identify the mRNA targets of these miRNAs and to understand their function, this study shows that miRNA profiling is a powerful technique for the assessment of nutritional status, which is useful for discriminating among very similar diseases.

Diets deficient in amino acids induce the expression of proteins that compete with miRNAs for binding to their target mRNAs, modulating the regulatory functions of these miRNAs. It has been reported that the expression of CAT-1 mRNA, encoding the high-affinity cationic amino acid transporter, is repressed by miR-122 in human hepatoma cells, but this repression is relieved if the cells are subjected to different types of stress such as amino acid deprivation, endoplasmic reticulum stress, or oxidative stress [12]. As the increase of CAT-1 activity was not accompanied with a change in mRNA levels and was also observed in cells treated with transcription inhibitors, it has been suggested that the augmented activity is consequential to the enhanced translation of preexisting mRNAs and is dependent on the binding of the AU-rich element-binding protein HuR to the $3^{\prime}$ UTR of CAT-1 mRNA, demonstrating the role of $3^{\prime}$ UTR-binding proteins in modulating the repression exerted by miRNAs [12]. 
The administration of essential amino acids can induce miRNA expression, sometimes by affecting the biogenesis of the miRNAs. In another study, it was found that the levels of miR-1, -23a, -208b, -499, and pri-miR-206 were increased in human muscle biopsies after the administration of a mix of essential amino acids containing histidine, isoleucine, leucine, lysine, methionine, phenylalanine, threonine, and valine [13]. Two notable observations were additionally reported: although miR-1 expression was upregulated, the level of its primary transcript pri-miR-1-2 was unaltered; and, in contrast, the levels of the precursor of miR-206 were upregulated, while those of its mature form were unaltered. These results point to the existence of regulation at the posttranscriptional level of miR-1 and miR-206 biogenesis by the anabolic influence of essential amino acid administration [13].

Carbohydrates

The decreased or augmented availability of glucose has been recognized as a factor that modulates miRNA expression. Glucose depletion has been shown to induce the murine miR-466h-5p through an increase in the acetylation of miR-466h-5p promoter region [14]. On the other extreme, hyperglycemia resulted in an increased expression of miR-21 in kidneys from type 1 diabetic mice as well as in a decreased expression of its target tumor suppressor protein phosphatase and tensin homolog deleted in chromosome 10 (PTEN), that is known to lead to renal cell hypertrophy characteristic of diabetic nephropathy [15]. In another report it was found that hyperglycemic conditions upregulated the expression of miR29c while decreasing the expression of its target Sprouty homolog 1 (Spry1), leading to an enhanced cell apoptosis and fibronectin synthesis characteristic of diabetic nephropathy [16]. The fact that in vivo inhibition of miR-29c activity ameliorated the progression of diabetic nephropathy is a very promising result that highlights the therapeutic potential of exogenously modulating the abundance of a particular miRNA [16].

Fatty Acids

Some fatty acids have been found to alter the expression of miRNAs. For example, the addition of butyrate, a short-chain fatty acid produced by bacteria colonizing the mammalian colon and that has been shown to have a role in differentiation, upregulated the expression of miR-10a, $-24,-122,-192$, and -375 [17]. The action of butyrate on differentiation can in part be explained by the fact that proteins involved in cell proliferation control such as HOXA1 and Notch1 were identified as the targets of miR-10a and miR-24, respectively [17]. It is really interesting to note that a molecule synthesized by the gut microbiota has such a role in the biological phenomena of cell differentiation by changing miRNA expression.

It is known that fish oil, which is rich in n-3 polyunsaturated fatty acids, has a chemopreventive action against certain digestive cancer types. Part of the explanation of its efficacy can be found in the fact that the downregulation of five tumor suppressor miRNAs (let$7 \mathrm{~d}$, miR-15b, -107, -191, -324-5p) caused by feeding rats with azoxymethane, a carcinogenic compound, can be reversed by the addition of fish oil to the rats' diet, suggesting that the chemopreventive action of fish oil is dependent on the changes in miRNA expression induced by its consumption [18].

Another class of fatty acids has been found to alter the expression of miRNAs in mice adipose tissue. As conjugated linoleic acids (CLA) have been reported to reduce fat deposition in animals, a study was performed to inquire if CLA administration altered the expression of miRNAs in mice adipose tissue [19]. The authors found that miR-107 and miR-143 were downregulated and miR-222 was upregulated in mice fed with a standard-fat diet and treated with CLA [19]. At present, the targets of these miRNAs have not been identified, thus the connection among the changes in miRNAs brought about by CLA administration and fat deposition is worth further study. 
High-fat diets have been linked to several serious diseases such as obesity, cardiovascular disease, and probably cancer. A number of recent studies have pinpointed to the putative role that changes in the expression of miRNAs have on the pathogenesis of diseases associated with high-fat diets. It was shown that the adult offspring of mothers that were fed a high-fat diet before conception presented reduced levels of let-7a, let-7b, let-7c, miR-26a, $-122,-192,-194,-483^{*},-494$, and -709 during pregnancy and lactation, while the liver expression of insulin-like growth factor-2 (Igf2) was increased, suggesting that an epigenetic mechanism is involved in explaining how dietary induced changes in gene expression is maintained until adulthood [20]. As let-7a has been reported to be the subject of repression by hypermethylation of its promoter in human lung cancer cells [21], this result confirms that some miRNAs can be regulated by epigenetic mechanisms. Furthermore, the fact that high-fat diets exert their noxious effects not only in individuals that are fed with such diets but also in their descendants is a very important topic to be considered in the design of public health policies.

A diet rich in fats and low in carbohydrates that is capable of inducing nonalcoholic fatty liver disease was found to downregulate the expression of miR-27, -122 , and -451 , while the expression of miR-200a, $-200 \mathrm{~b}$, and -429 was upregulated in rat liver, but the targets of the above-mentioned miRNAs have not been determined yet [22]. A different set of miRNAs was affected in obese mice induced by feeding a high-fat and high-cholesterol diet, including miR-16, -103, -107, and -451 that showed a decreased expression, while miR-351 and -669c showed an increased expression [23]. Under these same conditions, the expression of the fatty acid synthetase protein (FASN) was found to be increased [23]. As FASN has been identified as the target of miR-107, the downregulation of miR-107 could explain the observed upregulation of FASN in obese mice and the potential use of an augmented expression of miR-107 to decrease the synthesis of fatty acids [23]. Another study found that, while the silencing of miR-103 and -107 expression improves insulin sensitivity and glucose tolerance, its overexpression lead to impaired glucose homeostasis in mice fed a high-fat diet [24]. In this study, the protein caveolin-1, the principal component of caveolae that activates insulin signaling by stabilizing the insulin receptor (INSR), was identified as a direct target of miR103 and -107, showcasing these miRNAs as molecular targets for obesity and type 2 diabetes therapy [24]. Finally, in another report, the expression of miR-143 and -145 was found to be increased in mice fed a high-fat diet [25]. In particular, the augmented expression of miR-143 produced an increase in fasting plasma insulin levels, impaired glucose, and insulin tolerance - changes that were improved in miR-143-deficient mice [25]. This shows that miR-143 is a candidate for therapies to help in type 2 diabetes and obesity.

\section{Micronutrients Found to Have an Impact on miRNA Expression}

Some vitamins and their derivatives have been reported to affect the expression of miRNAs in different experimental models (table 2). It has been shown that, without an adequate supply of all-trans retinoic acid (atRA), a derivative of vitamin A, the transcriptional expression of retinoic acid-responsive genes is repressed [26]. The pharmacological administration of atRA is able to reverse the above-mentioned effect in a miRNA-mediated way [27]. It was found that nine miRNAs were upregulated (miR-15a, -15b, -16-1, -107, -223, -342, let-7a-3, let-7c, let-7d) and one was downregulated (miR-181b) by atRA administration. Additionally, some of the roles that atRA have in differentiation has been found to be mediated by miRNAs. For differentiation of human embryonal carcinoma cells into neural cells on atRA treatment, the miRNA miR-23 was found to be involved [28]. Other miRNAs (miR-9/9*, -124a and -125b) were found to be downregulated by the administration of atRA in a rat model of spina bifida [29], while the neural differentiation of neuroblastoma cells by treatment with atRA resulted in an increased expression of miR-10a and miR-10b, and these 
Table 2. Micronutrients known to affect the expression of miRNAs

\begin{tabular}{|c|c|c|c|}
\hline miRNA & Change & Type of cells & Reference \\
\hline \multicolumn{4}{|l|}{ Vitamins } \\
\hline \multicolumn{4}{|l|}{ Vitamin A derivatives } \\
\hline miR-15a, -15b, -16-1, -107, -223, -342 & & & \\
\hline let-7a-3, let-7c, let-7d & $\mathrm{U}$ & human promyelocytic cell line & 27 \\
\hline miR-181b & $\mathrm{D}$ & & \\
\hline miR-23 & $\mathrm{U}$ & human embryonal carcinoma cells & 28 \\
\hline $\mathrm{miR}-9 / 9^{*},-124 \mathrm{a},-125 \mathrm{~b}$ & $\mathrm{D}$ & rat model of spina bifida & 29 \\
\hline miR-10a, -10b & $\mathrm{U}$ & human neuroblastoma cells & 30,31 \\
\hline $\operatorname{miR}-21$ & $\mathrm{U}$ & human breast carcinoma cells & 32 \\
\hline \multicolumn{4}{|l|}{ Vitamin $\mathrm{B}_{9}$} \\
\hline miR-222 & $\mathrm{U}$ & $\begin{array}{l}\text { human lymphoblastoid cells } \\
\text { human whole blood }\end{array}$ & 33 \\
\hline let-7a, miR-17-92, $-21,-23,-130,-190$ & $\mathrm{U}$ & rat hepatocellular carcinoma & 34 \\
\hline $\operatorname{miR}-122$ & $\mathrm{D}$ & $\begin{array}{l}\text { rat hepatocellular carcinoma and } \\
\text { human primary hepatocellular carcinoma }\end{array}$ & \\
\hline miR-16, 34a, -17-92 cluster, -127 & $\mathrm{D}$ & rat hepatocellular carcinoma & 35 \\
\hline miR-16a, -34a, -127, -200b, & $\mathrm{D}$ & rat hepatocellular carcinoma & 36 \\
\hline \multicolumn{4}{|l|}{ Vitamin D } \\
\hline miR-125b & $\mathrm{D}$ & human breast adenocarcinoma cell lines & 37,38 \\
\hline miR-181a, -181b & $\mathrm{D}$ & human myeloid leukemia cells & 39 \\
\hline miR-32 & $\mathrm{D}$ & human acute myeloid leukemia cells & 40 \\
\hline miR-182 & $\mathrm{D}$ & human breast epithelial cells & 41 \\
\hline miR-21, -22, -29a, -29b, -134, -371-5p & & & \\
\hline$-1207-5 p$ & $\mathrm{U}$ & human prostate cancer cells & 42 \\
\hline \multirow{2}{*}{\multicolumn{4}{|c|}{ Vitamin E deficiency }} \\
\hline & & & \\
\hline miR-122a, $-125 b$ & $\mathrm{D}$ & rat liver & 43 \\
\hline \multicolumn{4}{|l|}{ Vitamin $\mathrm{H}$ (vitamin $\mathrm{B}_{7}$ or biotin) } \\
\hline miR-539 & $\mathrm{D}$ & human embryonic kidney cells & 45 \\
\hline miR-153 & $\mathrm{D}$ & human embryonic kidney cells & 46 \\
\hline \multicolumn{4}{|l|}{$\begin{array}{l}\text { Coenzyme } \mathrm{Q}_{10} \text { or ubiquinone } \\
\text { miR-146a }\end{array}$} \\
\hline miR-146a & $\mathrm{D}$ & human monocytic cells & 47 \\
\hline
\end{tabular}

miRNAs were found to be essential mediators of the effects of atRA [30, 31]. Finally, the administration of atRA produced an upregulation of miR-21 and a consequent decrease in the proliferation of breast carcinoma cells [32]. The anterior examples show the important roles that miRNAs play in differentiation induced by dietary components like atRA.

The lack of folic acid (vitamin $B_{9}$ ) in the nutrient medium of human lymphoblastoid cells in culture caused changes in the expression of miRNAs, which returned to control levels on readdition of folate to the growth medium [33]. The miRNA that showed the largest upregulation was miR-222, whose expression was also found to be increased in blood from individuals with folate deficiency [33]. In another study, rats fed a diet deficient in methyl donors (folate, methionine, and choline) developed hepatocellular carcinoma [34]. This result was accompanied with an increased expression of let-7a, miR-17-92, -21, -23, -130, and -190 and a decreased expression of miR-122 compared to the levels found in normally fed rats, and points to the assessment of miR-122 expression as a biomarker for liver cancer [34]. Also, it was found that miR-16, $-17-92,-34 \mathrm{a}$, and -127 presented a decreased expression in hepatocellular carcinoma induced by methyl deficiency [35]. A decreased expression of miR-16a, $-34 a$, 
-127 and -200b was shown early upon the development of hepatocellular carcinoma in rats fed a methyl-deficient diet [36].

The miRNA miR-125b was found to regulate in a negative manner the expression of the vitamin D receptor (VDR) [37]. This functional link between vitamin D receptor expression and miR-125b might explain why vitamin $\mathrm{D}$ receptor expression is upregulated while miR$125 \mathrm{~b}$ is downregulated in distinct types of cancer as the genomic locus that contains miR$125 \mathrm{~b}$ is deleted in several cancers [37]. Something similar is observed for the expression of the vitamin D3 hydroxylase, that catalyzes the inactivation of vitamin D, which was found to be overexpressed in several cancers and which is another of the targets of miR-125b [38]. In another work, it was reported that treatment of human myeloid leukemia cells with vitamin D limited their proliferation, an effect in part mediated by the downregulation of miR181a and -181b expression [39]. The same study also presented results that suggest that a high constitutive expression of miR-181a and $-181 \mathrm{~b}$ is conducive to the malignant phenotype, so vitamin $\mathrm{D}$ is functioning as a therapeutic agent via miR-181a and -181b downregulation [39]. Vitamin D was also shown to downregulate the expression of miR-32 in human acute myeloid leukemia-derived cells, preventing a blockage of differentiation saw in cells affected by this disorder [40]. Additionally, it was observed that the inhibition of miR-32 function by the administration of an RNA molecule that is complementary to miR-32 is able to increase the efficiency of cytotoxic therapy [40]. In a similar way, treatment with vitamin D was found to reverse the increase in cell death and in the expression of miR-182 in normal breast cells subjected to stress by growing in low-serum medium culture [41]. Another effect of vitamin D administration is the attenuation of proliferation of human prostate cancer cells when coadministered with testosterone; this treatment produced the upregulation of expression of miR-21, -22, -29a, -29b, -134, -371-5p, and -1207-5p and the downregulation of miR-17, -18 , and $-20 \mathrm{a}$, that are part of the miR-17/92 cluster [42].

Vitamin E deficiency has shown to result in a decrease of miR-122a and miR-125b abundance in rat liver [43]. These findings are very interesting if we take into account that dietary vitamin $\mathrm{E}$ is regulating the expression of miR-122a, which is the most abundant miRNA in rat and human liver and is known to participate in the regulation of lipid metabolism, and of miR-125b that has been associated to cancer and inflammation. The targets of these miRNAs have not been identified yet [43].

Biotin deficiency (vitamin $\mathrm{H}$ or vitamin $\mathrm{B}_{7}$ ) has been shown to alter carbon metabolism gene expression in three different eukaryotes (yeast, worm, and rat [44]), and a decrease in the expression of miR-539 is observed under these circumstances [45]. Additionally, it was found that the expression of the holocarboxylase synthetase enzyme responsible for attaching biotin to the carboxylases is regulated by miR-539 and miR-153 [45, 46].

Lastly, the induction of the anti-inflammatory miR-146a by bacterial lipopolysaccharide (LPS) has been reported to be partially overcome by the addition of coenzyme $\mathrm{Q}_{10}$ or ubiquinone, showing that this vitamin has an anti-inflammatory activity by modulating miR-146a expression [47].

\section{Effect of Phytochemicals on miRNA Expression}

The following phytochemicals have been reported to produce changes in miRNA expression (table 3).

The expression of miR-155 was found to be decreased by allyl isothiocyanate (AITC) administration [48]. As AITC is endorsed with a potent anti-inflammatory activity, it remains to be discerned how much of the anti-inflammatory effect can be explained by a decrease of miR-155 function by AITC administration [48]. 
García-Segura et al.: The Emerging Role of MicroRNAs in the Regulation of Gene Expression by Nutrients

Table 3. Phytochemicals known to affect the expression of miRNAs

\begin{tabular}{|c|c|c|c|}
\hline miRNA & Change & Type of cells & Reference \\
\hline \multicolumn{4}{|l|}{ Allyl isothiocyanate } \\
\hline miR-155 & $\mathrm{D}$ & murine macrophages and liver & 48 \\
\hline \multicolumn{4}{|l|}{ Capsaicin } \\
\hline $\operatorname{miR}-1,-16$ & $\mathrm{U}$ & mouse hind paw & 49 \\
\hline \multicolumn{4}{|l|}{ CDODA-Me and CDDO-Me } \\
\hline $\operatorname{miR}-27 \mathrm{a}$ & $\mathrm{D}$ & human colon cancer cell lines & 50 \\
\hline $\operatorname{miR}-27 \mathrm{a}$ & $\mathrm{D}$ & human pancreatic cancer cell lines & 51 \\
\hline \multicolumn{4}{|l|}{ Curcumin } \\
\hline miR-22 & $\mathrm{U}$ & human pancreatic cancer cells & 52 \\
\hline $\operatorname{miR}-199 a^{*}$ & $\mathrm{D}$ & & \\
\hline miR-200b, $-200 c$ & $\mathrm{U}$ & human pancreatic cancer cells & 53 \\
\hline $\operatorname{miR}-21$ & $\mathrm{D}$ & & \\
\hline $\operatorname{miR}-15 \mathrm{a},-16$ & $\mathrm{U}$ & human breast adenocarcinoma cell line & 54 \\
\hline $\operatorname{miR}-186^{*}$ & $\mathrm{D}$ & human lung adenocarcinoma cell line & 55 \\
\hline miR-21 & $\mathrm{D}$ & human colorectal cancer cells & 56 \\
\hline miR-203 & $\mathrm{U}$ & human bladder cancer cells & 57 \\
\hline \multicolumn{4}{|l|}{ EGCG } \\
\hline $\operatorname{miR}-16$ & $\mathrm{U}$ & human hepatocellular carcinoma cells & 58 \\
\hline \multicolumn{4}{|l|}{ Ellagitannin } \\
\hline let-7e, miR-370, $-373^{*},-526 \mathrm{~b}$ & $\mathrm{U}$ & human hepatocellular carcinoma cells & 59 \\
\hline let-7a, let-7c, let-7d & $\mathrm{D}$ & & \\
\hline \multicolumn{4}{|l|}{ Genistein } \\
\hline $\begin{array}{l}\text { let-7b-7c -7d -7e, } \\
\text { miR-200b, -200c }\end{array}$ & $\mathrm{D}$ & $\begin{array}{l}\text { gemcitabine-resistant pancreatic } \\
\text { human cells }\end{array}$ & 60 \\
\hline miR-146a & $\mathrm{U}$ & pancreatic cancer cells & 61 \\
\hline \multicolumn{4}{|l|}{$\mathrm{I} 3 \mathrm{C}$} \\
\hline miR-21, -31, -130a, -146b & $\mathrm{D}$ & mice lung cancer induced by vinyl carbamate & 62,63 \\
\hline let-7, miR-200 & $\mathrm{U}$ & pancreatic cancer cells & 60 \\
\hline \multicolumn{4}{|l|}{ Lectin } \\
\hline $\operatorname{miR}-135 a,-135 b$ & $\mathrm{D}$ & human colorectal cancer cells & 64 \\
\hline \multicolumn{4}{|l|}{ Nicotine } \\
\hline $\operatorname{miR}-140^{*}$ & $\mathrm{U}$ & rat adrenal pheochromocytoma cell lines & 65 \\
\hline \multicolumn{4}{|l|}{ Polyphenolics } \\
\hline miR-126 & $\mathrm{U}$ & human vascular endothelial cells & 66 \\
\hline \multicolumn{4}{|l|}{ Quercetin } \\
\hline miR-155 & $\mathrm{D}$ & murine macrophages & 67 \\
\hline miR-146a & $\mathrm{U}$ & human colon cells & 68 \\
\hline \multicolumn{4}{|l|}{ Resveratrol } \\
\hline miR-663 & $\mathrm{U}$ & $\begin{array}{l}\text { human monocytic cells } \\
\text { human blood monocytes }\end{array}$ & 69 \\
\hline $\operatorname{miR}-663$ & $\mathrm{U}$ & human colon cancer cells & 70 \\
\hline
\end{tabular}

An acute noxious stimulation of mouse hind paws with capsaicin produced an increase in the abundance of miR-1 and - 16 - miRNAs that have been previously found to be expressed in the mouse central nervous system [49]. It will be very interesting to see if the expression of miR-1 and -16 is also induced under conditions of chronic pain or if they are induced also in the gastrointestinal tract by ingestion of chili peppers.

It has been recently reported that the potent growth inhibitory and proapoptotic activities of the synthetic derivatives of glycyrrhetinic acid, which is found in licorice extracts, 
CDODA-Me, and CDDO-Me, can be ascribed to their effects on the expression of miR-27a $[50,51]$.

Curcumin or turmeric has been purported with anticancer effects. The administration of curcumin to human pancreatic cancer cells resulted in the upregulation of miR-22 and the downregulation of miR-199a* [52]. Additionally, a curcumin analog of curcumin, difluorinated curcumin, was able to induce apoptosis of human pancreatic cancer cell lines; under these conditions, miR-200b and $-200 \mathrm{c}$ were upregulated and miR-21 was downregulated, but at present it is not known if the changes in the expression of the miRNAs are involved in the induction of apoptosis [53]. The administration of curcumin has also been reported to affect the expression of other miRNAs. It has been shown to induce the expression of miR-15a and -16 [54] and of miR-186* [55], while repressing the expression of miR-21, that is found to be overexpressed in many tumors [56]. Curcumin has also been found to provoke epigenetic changes in the promoter of miR-203 [57].

The ester of epigallocatechin and gallic acid, epigallocatechin gallate (EGCG), is the most abundant catechin found in green tea and a potent antioxidant with putative therapeutic action against cancer. It has been recently found that the apoptosis induced by EGCG treatment was accompanied with a modification in the expression of 61 miRNAs (13 were upregulated and 48 were downregulated) in human liver-derived cells [58]. In particular, it was found that miR-16 expression was upregulated by EGCG administration.

Ellagitannins are polyphenolic compounds found in strawberries and various nuts that have an antioxidant, anti-inflammatory, antiproliferative, antitumor promoting and apoptosis-inducing properties. It has been reported that, following in vitro ellagitannin treatment of liver derived cells, 17 miRNAs were upregulated and 8 miRNAs were downregulated [59]. Among the upregulated miRNAs were let-7e, miR-370, miR-373*, and miR-526b, whereas let-7a, let-7c, and let-7d were found to be downregulated [59].

The isoflavone genistein has been claimed to have antioxidant, antihelmintic, and estrogen-mimicking properties. It has been reported that isoflavones alter miRNA expression patterns in pancreatic cancer cells [60]. The authors found that miRNAs let-7b, -7c, -7d, and $-7 \mathrm{e}$ and $\mathrm{miR}-200 \mathrm{~b}$ and $-200 \mathrm{c}$ were downregulated [60]. Finally, genistein has been shown to induce the expression of miR-146a in pancreatic cancer cells and have a dramatic effect on their metastatic activity [61].

Indole-3-carbinol (I3C), present in cruciferous plants such as broccoli, cabbage, and cauliflower, has been endowed with putative anticarcinogenic, antiatherogenic, and antioxidant effects. It has been found that, in a model of mice lung cancer induced by vinyl carbamate, the expression of miR-21, $-31,-130 \mathrm{a}$, and $-146 \mathrm{~b}$ was upregulated, while that of miR-1 and -143 was downregulated [62]. Interestingly, the upregulation of miR-21, $-31,-130 \mathrm{a}$, and $-146 \mathrm{~b}$ was reversed by I3C treatment $[62,63]$. I3C not only has direct effects on the expression of miRNAs, as it has been reported that the administration of 3,3'-diindolylmethane, a compound derived from I3C, caused the upregulation of miR-200 and let-7 miRNA families in pancreatic cells [60].

Mistletoe lectin-I (ML-I) has been used as complementary therapy in cancer. Li et al. [64] have reported that, besides the cytotoxic effects of ML-I, one component of ML-I named CM-1 has the ability to downregulate the expression of miR-135a and $-135 b$ by reducing the biogenesis of these molecules [64]. It has been found that nicotine augments the expression of miR-140* in rat adrenal cell lines, functioning in neuronal plasticity, and probably implicated in nicotine and other drug addiction [65].

Polyphenolics of acai and red muscadine grape showed anti-inflammatory actions when human vascular endothelial cells were stressed by high glucose or bacterial LPS [66]. Part of the anti-inflammatory effects can be explained as acai and red muscadine grape polyphenolic fraction is able to upregulate miR-126 expression [66]. 
The flavonoid quercetin is present in onions, apples, red wine, and tea. It has been reported that the inflammatory response induced by bacterial LPS that produced an increase of miR-155 is attenuated by quercetin and its methylated derivative isorhamnetin in murine macrophages [67]. In addition, the flavonols quercetin and kaempferol-3-rutinoside contained in yaupon holly (Ilex vomitoria) infusions, a variant of Ilex paraguariensis (yerba mate), have been shown to have anti-inflammatory properties in human normal colon cells by a reduction in the production of cytokines, in which the expression of miR-146a was found to be downregulated in colon cells treated with a flavonol-rich fraction of yaupon holly infusion [68]. This study also found that the repression of miR-146a expression by bacterial LPS was reversed by yaupon holly flavonol-rich fraction [68].

Resveratrol (trans-3,4',5-trihydroxystilbene) is an antioxidant found in the skin of red grapes and is thought to help in the prevention of cardiovascular disease, cancer, and inflammation. When administered to human monocytic cells and human blood monocytes, resveratrol has been shown to upregulate the expression of miR-663 [69]. Another effect of the administration of resveratrol has been that the increased expression of miR-155 elicited by a challenge with LPS was impaired. As miR-155 is a molecule involved in the innate immune response, its absence could in part explain the anti-inflammatory and anticancer activities of resveratrol [69]. The upregulation of miR-663 by resveratrol was also observed in human colon cancer cells [70].

Besides the effects that macro- and micro-nutrients and phytochemicals have on miRNA expression, it has been reported that food-derived miRNAs can influence gene expression. Also, some therapies based on the knowledge about the function of miRNAs are being devised for the treatment of diet-derived diseases. These topics will be discussed next.

\section{Therapeutic Applications of miRNAs on Dietary-Derived Diseases}

Some reports have been published that show that the overexpression of let-7 in mice results in impaired glucose tolerance and insulin resistance $[71,72]$, which can be explained by the repressor effect of let-7 on the expression of components of the insulin-PI3K-mTOR pathway such as INSR, insulin receptor substrate 2 (IRS2), and insulin-like growth factor 1 receptor (IGF1R) [72]. Therefore, in genetically obese mice fed a high-fat diet, silencing of let-7 expression by an antimiR, a chemically modified antisense oligonucleotide that has a sequence complimentary to that of let-7 that impedes let-7 from binding to their mRNA targets (INSR, IRS2, and IGF1R mRNAs), was used successfully to improve glucose tolerance and insulin sensitivity $[71,72]$.

Another miRNA has a great potential as a therapeutic target for metabolic syndrome: miR-122 is highly expressed in the liver, where it is an important regulator in cholesterol and fatty acid metabolism [73]. It has been found that miR-122 inhibition by antisense oligonucleotides in normal mice resulted in increased fatty acid oxidation, reduced plasma cholesterol levels, and decreased fatty acid and cholesterol synthesis rates [73]. The inhibition of miR-122 in a diet-induced obesity mouse model has also shown a decrease in plasma cholesterol levels [73]. As miR-122 inhibition caused a dose-dependent decrease in plasma cholesterol in nonhuman primates, miR-122 has become a very interesting candidate as a therapeutic agent in the treatment of hypercholesterolemia in humans [74]. These results open new and exciting possibilities in which knowledge about the function of miRNAs and their targets can be used in the treatment of diet-derived diseases such as type 2 diabetes and obesity. 


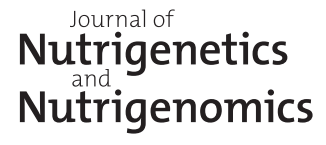

\begin{tabular}{l|l}
\hline J Nutrigenet Nutrigenomics 2013;6:16-31 \\
\hline DOI: $\underline{10.1159 / 000345826}$ & $\begin{array}{l}\text { @ } 2013 \text { S. Karger AG, Basel } \\
\text { www.karger.com/jnn }\end{array}$ \\
\hline
\end{tabular}

García-Segura et al.: The Emerging Role of MicroRNAs in the Regulation of Gene Expression by Nutrients

\section{Food-Derived miRNAs That Putatively Affect Commensal Gene Expression}

Recently, a report has shown that miR-168a, a miRNA found in rice, is present in sera of Chinese healthy donors [75]. Additionally, it has been found that the amount of miR-168a was increased in mouse liver after mice were fed rice; interestingly, the level of the identified target of rice miR-168a, mouse low-density lipoprotein receptor adapter protein 1 (LDLRAP1) mRNA was severely decreased and, as a consequence, an increase in the plasma lowdensity lipoprotein cholesterol complex was observed 3 days after rice administration [75]. Apparently some food-derived miRNAs are stable to cooking, are resistant to enzymatic digest in the gastrointestinal tract, are stable in animal serum, and are able to regulate gene expression in the organisms that ingest them. Another example has just recently been reported showing that bacterial regulatory RNAs can affect gene expression in an invertebrate [76]. Routinely, Caenorhabditis elegans is raised on Escherichia coli in laboratories. It has been found that, if small RNAs of E. coli DsrA or OxyS are induced by low temperature or oxidative stress, the nematodes fed with them present a decrease in longevity or a defect in chemosensory abilities, respectively [76]. The same study also showed that DsrA and OxyS produce a decrease in the expression of $C$. elegans genes F42G9.6 and che-2 that encode a diacylglycerol lipase and a member of the WD40 protein family involved in food searching activities. If these results are confirmed, it will be very interesting to see if other examples of food-derived miRNAs or bacterial regulatory RNAs that affect commensal gene expression are found.

\section{Conclusions}

miRNAs constitute a novel class of gene regulators in eukaryotic cells. So far, we have been able to see just the tip of the iceberg in terms of all the different functions that miRNAs can perform. As expression profiles of miRNAs change under various pathological conditions, they are considered as useful biomarkers for diagnosis and prognosis. In the context of nutrition, as diet has been found to modulate miRNA expression, miRNA profiling could be a useful aid in the assessment of the nutritional status in dietary intervention studies. Furthermore, as aberrant miRNA expression has been correlated with cancer progression, miRNAs are becoming very attractive targets for cancer therapy. In that sense, the fact that dietary components are known to regulate the expression of miRNAs could be used for designing therapeutic approaches in which nutrients and phytochemicals known to possess cancer chemopreventive activities that target miRNAs are used in combination with conventional therapies to improve the treatment of cancer patients and for the prevention of cancer recurrence.

Moreover, the potential of food-derived miRNAs to affect host gene expression is a really exciting discovery. If these results are confirmed and more examples are found, the phrase 'you are what you eat' should be complemented with 'and some of the food-derived miRNAs are capable of regulating the expression of your genes'. In such a situation, we will be witnessing another case of cross-kingdom gene regulation, similar in concept to the regulation of host genes by viral miRNAs [77], and food-derived exogenous miRNAs should be considered as novel nutrient components, just like amino acids or vitamins. In fact, miRNAs with immunomodulatory activities have been found in human breast milk in the first 6 months of lactation, where they can putatively regulate the infant's immune system development [78].

Finally, the knowledge about the function of miRNAs and their targets as well as the different cell processes in which miRNAs are involved will be useful to treat some diet-derived 


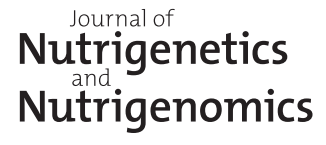

\begin{tabular}{l|l}
\hline J Nutrigenet Nutrigenomics 2013;6:16-31 \\
\hline DOI: $\underline{10.1159 / 000345826}$ & $\begin{array}{l}\text { @ } 2013 \text { S. Karger AG, Basel } \\
\text { www.karger.com/jnn }\end{array}$ \\
\hline
\end{tabular}

García-Segura et al.: The Emerging Role of MicroRNAs in the Regulation of Gene Expression by Nutrients

diseases by antimiR or supplementation technologies [79]. The study of the relationship between nutrition and RNA-based regulation will undoubtedly give rise to many surprises in the near future.

\section{Acknowledgments}

The authors wish to thank Antonio Velázquez-Arellano for critically reading this review and the support by Programa de Apoyo a Proyectos de Investigación e Innovación Tecnológica (PAPIIT), Dirección General de Asuntos del Personal Académico (DGAPA), Universidad Nacional Autónoma de Mexico (UNAM), project IN209310-3. L.G.-S. thankfully acknowledges a PhD fellowship from CONACYT, Mexico.

\section{References}

1 Wu GD, Chen J, Hoffmann C, Bittinger K, Chen YY, Keilbaugh SA, Bewtra M, Knights D, Walters WA, Knight R, Sinha R, Gilroy E, Gupta K, Baldassano R, Nessel L, Li H, Bushman FD, Lewis JD: Linking long-term dietary patterns with gut microbial enterotypes. Science 2011;334:105-108.

$\longrightarrow 2$ Fenech M, El-Sohemy A, Cahill L, Ferguson LR, French TA, Tai ES, Milner J, Koh WP, Xie L, Zucker M, Buckley M, Cosgrove L, Lockett T, Fung KY, Head R: Nutrigenetics and nutrigenomics: viewpoints on the current status and applications in nutrition research and practice. J Nutrigenet Nutrigenomics 2011;4:69-89.

3 Thomason MK, Storz G: Bacterial antisense RNAs: how many are there, and what are they doing? Annu Rev Genet 2010;44:167-188.

4 Carthew RW, Sontheimer EJ: Origins and mechanisms of miRNAs and siRNAs. Cell 2009;136:642-655.

5 Fang Z, Rajewsky N: The impact of miRNA target sites in coding sequences and in 3'UTRs. PLoS One 2011;6:e18067.

6 Zhang X, Rossi JJ: Phylogenetic comparison of small RNA-triggered transcriptional gene silencing. J Biol Chem 2011; 286:29443-29448.

7 Friedman RC, Farh KK, Burge CB, Bartel DP: Most mammalian mRNAs are conserved targets of microRNAs. Genome Res 2009;19:92-105.

8 Chiou TJ: The role of microRNAs in sensing nutrient stress. Plant Cell Environ 2007;30:323-332.

- Holtz J, Pasquinelli AE: Uncoupling of lin-14 mRNA and protein repression by nutrient deprivation in Caenorhabditis elegans. RNA 2009;15:400-405.

10 Leung AK, Sharp PA: MicroRNA functions in stress responses. Mol Cell 2010;40:205-215.

-11 Dolganiuc A, Petrasek J, Kodys K, Catalano D, Mandrekar P, Velayudham A, Szabo G: MicroRNA expression profile in Lieber-DeCarli diet-induced alcoholic and methionine-choline deficient diet-induced nonalcoholic steatohepatitis models in mice. Alcohol Clin Exp Res 2009;33:1704-1710.

$\checkmark 12$ Bhattacharyya SN, Habermacher R, Martine U, Closs EI, Filipowicz W: Relief of microRNA-mediated translational repression in human cells subjected to stress. Cell 2006;125:1111-1124.

13 Drummond, MJ, Glynn, EL, Fry CS, Dhanani S, Volpi E, Rasmussen BB: Essential amino acids increase microRNA-499, -208b, and -23a and downregulate myostatin and myocyte enhancer factor 2C mRNA expression in human skeletal muscle. J Nutr 2009;139:2279-2284.

$\checkmark 14$ Druz A, Betenbaugh M, Shiloach J: Glucose depletion activates mmu-miR-466h-5p expression through oxidative stress and inhibition of histone deacetylation. Nucleic Acids Res 2012;40:7291-7302.

15 Dey N, Das F, Mariappan MM, Mandal CC, Ghosh-Choudhury N, Kasinath BS, Choudhury GG: MicroRNA-21 orchestrates high glucose-induced signals to TOR complex 1, resulting in renal cell pathology in diabetes. J Biol Chem 2011;286:25586-25603.

-16 Long J, Wang Y, Wang W, Chang BH, Danesh FR: MicroRNA-29c is a signature microRNA under high glucose conditions that targets Sprouty homolog 1, and its in vivo knockdown prevents progression of diabetic nephropathy. J Biol Chem 2011;286:11837-11848.

17 Tzur G, Levy A, Meiri E, Barad O, Spector Y, Bentwich Z, Mizrahi L, Katzenellenbogen M, Ben-Shushan E, Reubinoff BE, Galun E: MicroRNA expression patterns and function in endodermal differentiation of human embryonic stem cells. PLoS One 2008;3:e3726.

18 Davidson LA, Wang N, Shah MS, Lupton JR, Ivanov I, Chapkin RS: $n$-3 polyunsaturated fatty acids modulate carcinogen-directed non-coding microRNA signatures in rat colon. Carcinogenesis 2009;30:2077-2084.

19 Parra P, Serra F, Palou A: Expression of adipose microRNAs is sensitive to dietary conjugated linoleic acid treatment in mice. PLoS One 2010;5:e13005.

20 Zhang J, Zhang F, Didelot X, Bruce KD, Cagampang FR, Vatish M, Hanson M, Lehnert H, Ceriello A, Byrne CD: Maternal high fat diet during pregnancy and lactation alters hepatic expression of insulin like growth factor-2 and key microRNAs in the adult offspring. BMC Genomics 2009;10:478. 


\section{Nutrigenetics Nutrigenomics}

\begin{tabular}{l|l}
\hline J Nutrigenet Nutrigenomics 2013;6:16-31 \\
\hline DOI: $10.1159 / 000345826$ & $\begin{array}{l}\odot 2013 \text { S. Karger AG, Basel } \\
\text { www.karger.com/jnn }\end{array}$ \\
\hline
\end{tabular}

García-Segura et al.: The Emerging Role of MicroRNAs in the Regulation of Gene Expression by Nutrients

21 Brueckner B, Stresemann C, Kuner R, Mund C, Musch T, Meister M, Sultmann H, Lyko F: The human let-7a-3 locus contains an epigenetically regulated microRNA gene with oncogenic function. Cancer Res 2007;67:1419-1423.

22 Alisi A, Da Sacco L, Bruscalupi G, Piemonte F, Panera N, De Vito R, Leoni S, Bottazzo GF, Masotti A, Nobili V: Mirnome analysis reveals novel molecular determinants in the pathogenesis of diet-induced nonalcoholic fatty liver disease. Lab Invest 2011;91:283-293.

23 Park JH, Ahn J, Kim S, Kwon DY, Ha TY: Murine hepatic miRNAs expression and regulation of gene expression in diet-induced obese mice. Mol Cells 2011;31:33-38.

24 Trajkovski M, Hausser J, Soutschek J, Bhat B, Akin A, Zavolan M, Heim MH, Stoffel M: MicroRNAs 103 and 107 regulate insulin sensitivity. Nature 2011;474:649-653.

25 Jordan SD, Krüger M, Willmes DM, Redemann N, Wunderlich FT, Brönneke HS, Merkwirth C, Kashkar H, Olkkonen VM, Böttger T, Braun T, Seibler J, Brüning JC: Obesity-induced overexpression of miRNA-143 inhibits insulin-stimulated AKT activation and impairs glucose metabolism. Nat Cell Biol 2011;13:434-446.

26 Melnick A, Licht JD: Deconstructing a disease: RARalpha, its fusion partners, and their roles in the pathogenesis of acute promyelocytic leukemia. Blood 1999;93:3167-3215.

27 Garzon R, Pichiorri F, Palumbo T, Visentini M, Aqeilan R, Cimmino A, Wang H, Sun H, Volinia S, Alder H, Calin GA, Liu CG, Andreeff M, Croce CM: MicroRNA gene expression during retinoic acid-induced differentiation of human acute promyelocytic leukemia. Oncogene 2007;26:4148-4157.

Kawasaki H, Taira K: Functional analysis of microRNAs during the retinoic acid-induced neuronal differentiation of human NT2 cells. Nucleic Acids Res Suppl 2003;3:243-244.

29 Zhao JJ, Sun DG, Wang J, Liu SR, Zhang CY, Zhu MX, Ma X: Retinoic acid downregulates microRNAs to induce abnormal development of spinal cord in spina bifida ratmodel. Childs Nerv Syst 2008;24:485-492.

-30 Meseguer S, Mudduluru G, Escamilla JM, Allgayer H, Barettino D: MicroRNAs-10a and -10b contribute to retinoic acid-induced differentiation of neuroblastoma cells and target the alternative splicing regulatory factor SFRS1 (SF2/ ASF). J Biol Chem 2011,286:4150-4164.

-31 Foley NH, Bray I, Watters KM, Das S, Bryan K, Bernas T, Prehn JH, Stallings RL: MicroRNAs 10a and 10b are potent inducers of neuroblastoma cell differentiation through targeting of nuclear receptor corepressor 2. Cell Death Differ 2011;18:1089-1098.

-32 Terao M, Fratelli M, Kurosaki M, Zanetti A, Guarnaccia V, Paroni G, Tsykin A, Lupi M, Gianni M, Goodall GJ, Garattini E: Induction of miR-21 by retinoic acid in estrogen receptor-positive breast carcinoma cells: biological correlates and molecular targets. J Biol Chem 2011;286:4027-4042.

33 Marsit CJ, Eddy K, Kelsey KT: MicroRNA responses to cellular stress. Cancer Res 2006;66:10843-10848.

-34 Kutay H, Bai S, Datta J, Motiwala T, Pogribny I, Frankel W, Jacob ST, Ghoshal K: Downregulation of miR-122 in the rodent and human hepatocellular carcinomas. J Cell Biochem 2006;99:671-678.

-35 Pogribny IP, Tryndyak VP, Ross SA, Beland FA: Differential expression of microRNAs during hepatocarcinogenesis induced by methyl deficiency in rats. Nutr Rev 2008;66(suppl 1):S33-S35.

- 36 Tryndyak VP, Ross SA, Beland FA, Pogribny IP: Down-regulation of the microRNAs miR-34a, miR-127, and miR200b in rat liver during hepatocarcinogenesis induced by a methyl-deficient diet. Mol Carcinog 2009;48:479-487.

-37 Mohri T, Nakajima M, Takagi S, Komagata S, Yokoi T: MicroRNA regulates human vitamin D receptor. Int J Cancer 2009; 125:1328-1333.

-38 Komagata S, Nakajima M, Takagi S, Mohri T, Taniya T, Yokoi T: Human CYP24 catalyzing the inactivation of calcitriol is post-transcriptionally regulated by miR-125b. Mol Pharmacol 2009;76:702-709.

-39 Wang X, Gocek E, Liu CG, Studzinski GP: MicroRNAs181 regulate the expression of p27Kip1 in human myeloid leukemia cells induced to differentiate by 1,25-dihydroxyvitamin D3. Cell Cycle 2009;8:736-741.

40 Gocek E, Wang X, Liu X, Liu CG, Studzinski GP: MicroRNA-32 upregulation by 1,25-dihydroxyvitamin D3 in human myeloid leukemia cells leads to Bim targeting and inhibition of AraC-induced apoptosis. Cancer Res 2011;71:62306239.

-41 Peng X, Vaishnav A, Murillo G, Alimirah F, Torres KE, Mehta RG: Protection against cellular stress by 25-hydroxyvitamin D3 in breast epithelial cells. J Cell Biochem 2010;110:1324-1333.

42 Wang WL, Chatterjee N, Chittur SV, Welsh J, Tenniswood MP: Effects of 1 $\alpha, 25$ dihydroxyvitamin D3 and testosterone on miRNA and mRNA expression in LNCaP cells. Mol Cancer 2011;10:58.

43 Gaedicke S, Zhang X, Schmelzer C, Lou Y, Doering F, Frank J, Rimbach G: Vitamin E dependent microRNA regulation in rat liver. FEBS Lett 2008;582:3542-3546.

-44 Ortega-Cuellar D, Hernandez-Mendoza A, Moreno-Arriola E, Carvajal-Aguilera K, Perez-Vazquez V, Gonzalez-Alvarez R, Velazquez-Arellano A: Biotin starvation with adequate glucose provision causes paradoxical changes in fuel metabolism gene expression similar in rat (Rattus norvegicus), nematode (Caenorhabditis elegans) and yeast (Saccharomyces cerevisiae). J Nutrigenet Nutrigenomics 2010;3:18-30.

45 Bao B, Rodriguez-Melendez R, Wijeratne SS, Zempleni J: Biotin regulates the expression of holocarboxylase synthetase in the miR-539 pathway in HEK-293 cells. J Nutr 2010;140:1546-1551.

-46 Bao B, Rodriguez-Melendez R, Zempleni J: Cytosine methylation in miR-153 gene promoters increases the expression of holocarboxylase synthetase, thereby increasing the abundance of histone H4 biotinylation marks in HEK-293 human kidney cells. J Nutr Biochem 2012;23:635-639.

-47 Schmelzer C, Kitano M, Rimbach G, Niklowitz P, Menke T, Hosoe K, Frank Döring F: Effects of ubiquinol-10 on microRNA-146a expression in vitro and in vivo. Mediators Inflamm 2009;2009:415437. 


\section{Nutrigenetics Nutrigenomics}

\begin{tabular}{l|l}
\hline J Nutrigenet Nutrigenomics 2013;6:16-31 \\
\hline DOI: $\underline{10.1159 / 000345826}$ & $\begin{array}{l}\text { @ } 2013 \text { S. Karger AG, Basel } \\
\text { www.karger.com/jnn }\end{array}$ \\
\hline
\end{tabular}

García-Segura et al.: The Emerging Role of MicroRNAs in the Regulation of Gene Expression by Nutrients

48 Wagner AE, Boesch-Saadatmandi C, Dose J, Schultheiss G, Rimbach G: Anti-inflammatory potential of allyl-isothiocyanate-role of Nrf2, NFкB and microRNA-155. J Cell Mol Med 2012;16:836-843.

-49 Kusuda R, Cadetti F, Ravanelli MI, Sousa TA, Zanon S, De Lucca FL, Lucas G: Differential expression of microRNAs in mouse pain models. Mol Pain 2011;7:17.

-50 Chintharlapalli S, Papineni S, Abdelrahim M, Abudayyeh A, Jutooru I, Chadalapaka G, Wu F, Mertens-Talcott S, Vanderlaag K, Cho SD, Smith R 3rd, Safe S: Oncogenic microRNA-27a is a target for anticancer agent methyl 2-cyano3,11-dioxo-18beta-olean-1,12-dien-30-oate in colon cancer cells. Int J Cancer 2009;125:1965-1974.

-51 Jutooru I, Chadalapaka G, Abdelrahim M, Riyaz Basha M, Samudio I, Konopleva M, Andreeff M, Safe S: Methyl 2-cyano-3,12-dioxooleana-1,9-dien-28-oate decreases specificity protein transcription factors and inhibits pancreatic tumor growth: role of microRNA 27a. Mol Pharmacol 2010;78:226-236.

-52 Sun M, Estrov Z, Ji Y, Coombes KR, Harris DH, Kurzrock R: Curcumin (diferuloylmethane) alters the expression profiles of microRNAs in human pancreatic cancer cells. Mol Cancer Ther 2008;7:464-473.

53 Ali S, Ahmad A, Banerjee S, Padhye S, Dominiak K, Schaffert JM, Wang Z, Philip PA, Sarkar FH: Gemcitabine sensitivity can be induced in pancreatic cancer cells through modulation of miR-200 and miR-21 expression by curcumin or its analogue CDF. Cancer Res 2010;70:3606-3617.

54 Yang J, Cao Y, Sun J, Zhang Y: Curcumin reduces the expression of Bcl-2 by upregulating miR-15a and miR-16 in MCF7 cells. Med Oncol 2010;27:1114-1118.

55 Zhang J, Zhang T, Ti X, Shi J, Wu C, Ren X, Yin H: Curcumin promotes apoptosis in A549/DDP multidrug-resistant human lung adenocarcinoma cells through an miRNA signaling pathway. Biochem Biophys Res Commun 2010;399: $1-6$.

Mudduluru G, George-William JN, Muppala S, Asangani IA, Regalla K, Nelson LD, Allgayer H: Curcumin regulates miR-21 expression and inhibits invasion and metastasis in colorectal cancer. Biosci Rep 2011;31:185-197.

57 Saini S, Arora S, Majid S, Shahryari V, Chen Y, Deng G, Yamamura S, Ueno K, Dahiya R: Curcumin modulates microRNA-203 mediated regulation of the Src-Akt axis in bladder cancer. Cancer Prev Res (Phila) 2011;4:1698-1709.

58 Tsang WP, Kwok TT: Epigallocatechin gallate up-regulation of miR-16 and induction of apoptosis in human cancer cells. J Nutr Biochem 2010;21:140-146.

-59 Wen XY, Wu SY, Li ZQ, Liu ZQ, Zhang JJ, Wang GF, Jiang ZH, Wu SG: Ellagitannin (BJA3121), an anti-proliferative natural polyphenol compound, can regulate the expression of miRNAs in HepG2 cancer cells. Phytother Res 2009; 23:778-784.

60 Li Y, VandenBoom TG II, Kong D, Wang Z, Ali S, Philip PA, Sarkar FH: Up-regulation of miR-200 and let-7 by natural agents leads to the reversal of epithelial-to-mesenchymal transition in gemcitabine resistant pancreatic cancer cells. Cancer Res 2009;69:6704-6712.

61 Li Y, Vandenboom TG II, Wang Z, Kong D, Ali S, Philip PA, Sarkar FH: miR-146a suppresses invasion of pancreatic cancer cells. Cancer Res 2010;70:1486-1495.

62 Melkamu T, Zhang X, Tan J, Zeng Y, Kassie F: Alteration of microRNA expression in vinyl-carbamate-induced mouse lung tumors and modulation by the chemopreventive agent indole-3-carbinol. Carcinogenesis 2010;31:252-258.

63 Iorio MV, Croce CM: MicroRNAs in cancer: small molecules with a huge impact. J Clin Oncol 2009;27:5848-5856.

64 Li LN, Zhang HD, Zhi R, Yuan SJ: Down-regulation of some miRNAs by degrading their precursors contributes to anti-cancer effect of mistletoe lectin-I. Br J Pharmacol 2011;162:349-364.

65 Huang W, Li MD: Nicotine modulates expression of miR-140*, which targets the $3^{\prime}$ - untranslated region of dynamin 1 gene (Dnm1). Int J Neuropsychopharmacol 2009;12:537-546.

66 Noratto GD, Angel-Morales G, Talcott ST, Mertens-Talcott SU: Polyphenolics from açaí ( Euterpe oleracea Mart.) and red muscadine grape (Vitis rotundifolia) protect human umbilical vascular endothelial cells (HUVEC) from glucoseand lipopolysaccharide (LPS)-induced inflammation and target microRNA-126. J Agric Food Chem 2011;59:79998012.

67 Boesch-Saadatmandi C, Loboda A, Wagner AE, Stachurska A, Jozkowicz A, Dulak J, Döring F, Wolffram S, Rimbach G: Effect of quercetin and its metabolites isorhamnetin and quercetin-3-glucuronide on inflammatory gene expression: role of miR-155. J Nutr Biochem 2011;22:293-299.

68 Noratto GD, Kim Y, Talcott ST, Mertens-Talcott SU: Flavonol-rich fractions of yaupon holly leaves (Ilex vomitoria, Aquifoliaceae) induce microRNA-146a and have anti-inflammatory and chemopreventive effects in intestinal myofibroblast CCD-18Co cells. Fitoterapia 2011;82:557-569.

69 Tili E, Michaille JJ, Adair B, Alder H, Limagne E, Taccioli C, Ferracin M, Delmas D, Latruffe N, Croce CM: Resveratrol decreases the levels of miR-155 by upregulating miR-663, a microRNA targeting JunB and JunD. Carcinogenesis 2010;31:1561-1566.

70 Tili E, Michaille JJ, Alder H, Volinia S, Delmas D, Latruffe N, Croce CM: Resveratrol modulates the levels of microRNAs targeting genes encoding tumor-suppressors and effectors of TGFbeta signaling pathway in SW480 cells. Biochem Pharmacol 2010;80:2057-2065.

71 Frost RJ, Olson EN: Control of glucose homeostasis and insulin sensitivity by the Let-7 family of microRNAs. Proc Natl Acad Sci USA 2011;108:21075-21080.

72 Zhu H, Shyh-Chang N, Segrè AV, Shinoda G, Shah SP, Einhorn WS, Takeuchi A, Engreitz JM, Hagan JP, Kharas MG, Urbach A, Thornton JE, Triboulet R, Gregory RI, DIAGRAM Consortium, MAGIC Investigators, Altshuler D, Daley GQ: The Lin28/let-7 axis regulates glucose metabolism. Cell 2011;147:81-94. 
73 Esau C, Davis S, Murray SF, Yu XX, Pandey SK, Pear M, Watts L, Booten SL, Graham M, McKay R, Subramanian A, Propp S, Lollo BA, Freier S, Bennett CF, Bhanot S, Monia BP: miR-122 regulation of lipid metabolism revealed by in vivo antisense targeting. Cell Metab 2006;3:87-98.

74 Elmen J, Lindow M, Schütz S, Lawrence M, Petri A, Obad S, Lindholm M, Hedtjärn M, Hansen HF, Berger U, Gullans S, Kearney P, Sarnow P, Straarup EM, Kauppinen S: LNA-mediated microRNA silencing in non-human primates. Nature 2008;452:896-899.

75 Zhang L, Hou D, Chen X, Li D, Zhu L, Zhang Y, Li J, Bian Z, Liang X, Cai X, Yin Y, Wang C, Zhang T, Zhu D, Zhang $\mathrm{D}, \mathrm{Xu}$ J, Chen Q, Ba Y, Liu J, Wang Q, Chen J, Wang J, Wang M, Zhang Q, Zhang J, Zen K, Zhang CY: Exogenous plant miR-168a specifically targets mammalian LDLRAP1:evidence of cross-kingdom regulation by microRNA. Cell Res 2012;22:107-126.

76 Liu H, Wang X, Wang H-D, Wu J, Ren J, Meng L, Wu Q, Dong H, Wu J, Kao T-Y, Ge Q, Wu Z, Yuh C-H, Shan G: Escherichia coli noncoding RNAs can affect gene expression and physiology of Caenorhabditis elegans. Nat Commun 2012; 3:1073.

77 Skalsky RL, Cullen BR: Viruses, microRNAs, and host interactions. Annu Rev Microbiol 2010;64:123-141.

78 Kosaka N, Izumi H, Sekine K, Ochiya T: microRNA as a new immune-regulatory agent in breast milk. Silence 2010; 1:7.

79 Stenvang J, Petri A, Lindow M, Obad S, Kauppinen S: Inhibition of microRNA function by antimiR oligonucleotides. Silence 2012;3:1. 